\title{
Dissolved organic carbon distributions in the Bransfield and Gerlache Straits, Antarctica
}

\author{
Doval M.D., X.A. Álvarez-Salgado, C.G. Castro, F.F. Pérez \\ C.S.I.C. Instituto de Investigaciones Marinas. Eduardo Cabello 6, E-36208 Vigo, Spain \\ e-mail: marylo@iim.csic.es
}

(revised version)

Deep-Sea Research, part II

October 1999 


\section{Abstract}

During FRUELA'95 cruise, seawater samples were collected at the Bransfield and Gerlache Straits for the analysis of dissolved organic carbon (DOC) profiles throughout the water column. An excess of DOC probably derived from phytogenic material was

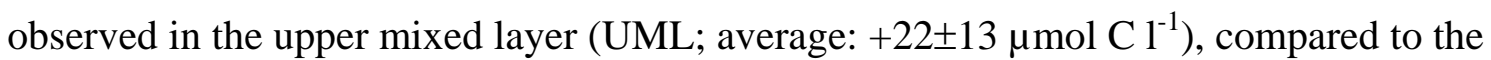

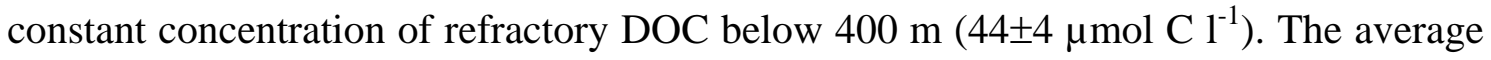
excess DOC concentration was higher than the particulate organic carbon concentration, indicating the major contribution of DOC to carbon export in this area. However, large

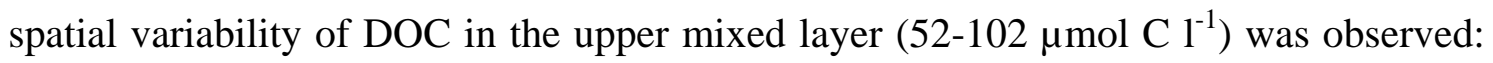
excess DOC contributed from 15 to $57 \%$ to the actual DOC concentration. Maximum average DOC concentrations in the UML were recorded in the Gerlache Strait (71 $\mu \mathrm{mol}$ $\mathrm{C}^{-1}$ ) and in the Gerlache-Bransfield confluence (80 $\mu$ mol $\mathrm{C}^{-1}$ ), whereas minimum

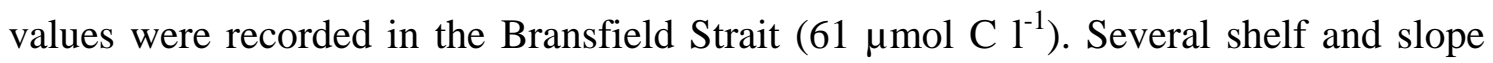
stations showed a slight increase of DOC (5-10 $\left.\mu \mathrm{mol} \mathrm{C} \mathrm{l}^{-1}\right)$ in the deep layer, which might be related to organic matter release from the underlying sediments. Considering the net DOC release from phytoplankton, the low bacterial biomass and the reduced vertical DOC export, the DOC excess could build up in about 6 days for most of the sampling stations. The probable fate of the DOC excess is the eastwards horizontal transport by the Bransfield Current out the study area.

Keywords: Dissolved Organic Carbon, Particulate Organic Matter, Bransfield and Gerlache Straits, Antarctica, Southern Ocean 


\section{Introduction}

A dissolved organic matter (DOM) excess in surface ocean waters compared to deep waters is a commonly observed worldwide trend (Thingstad et al. 1997, and references therein). The contribution of this amount of DOM to the export of primary production is a subject of discussion nowadays (e.g. Legendre and Le Févre, 1995; Hansell and Carlson 1998a). The excess surface DOM can be: 1) consumed by heterotrophic bacteria; 2) exported downwards by turbulent diffusion or during deep winter convection (Copin-Montégut and Avril, 1993; Carlson et al., 1994); or 3) transported out of the production area by horizontal circulation (Legendre and Le Févre, 1995; Hansell and Waterhouse, 1997). This excess DOM has been hypothesized to be composed of semi-labile and labile material with recycling time of days to months. However, deep DOC is composed mostly of refractory material with recycling time of 10 1-3 years (Copin-Montégut and Avril, 1993; Carlson and Ducklow, 1995). In agreement with the most recently studies, refractory DOC is not constant for all deep waters around the world; deep DOC concentrations decrease about $14 \mu \mathrm{M}-\mathrm{C}$ from the northern North Atlantic Ocean to the northern North Pacific Ocean (Hansell and Carlson, 1998b).

There exists a wide range of measured DOC concentrations in the Southern

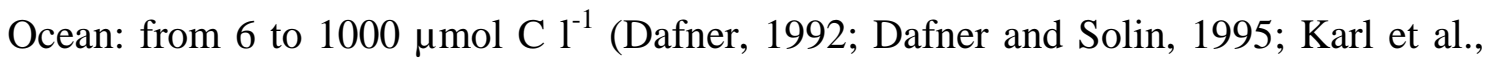

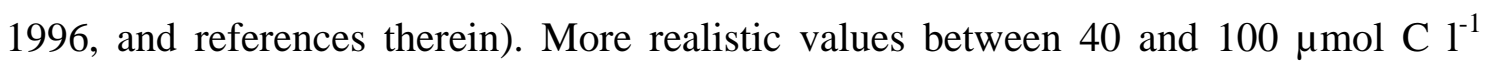
were measured in the Weddell Sea (Skoog and Wedborg, 1994; Wedborg et al., 1998),

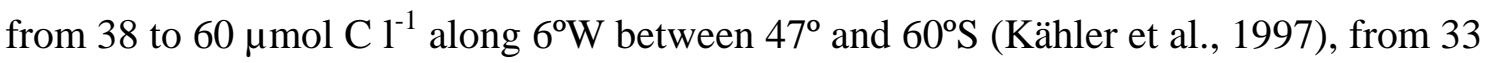

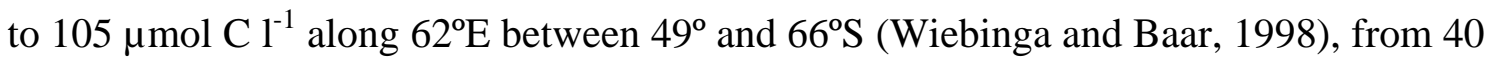

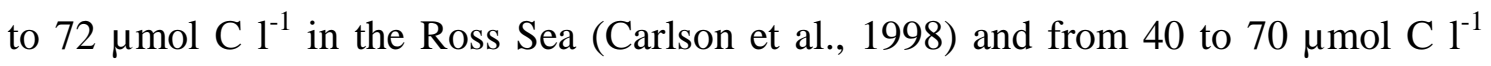
along $170^{\circ} \mathrm{E}$ and $170^{\circ} \mathrm{W}$ between $50^{\circ}$ and $67^{\circ} \mathrm{S}$ (Doval and Hansell, 2000). The wider 
ranges in the earlier papers were related to analytical difficulties or special marine environments (Dawson et al., 1985).

Antarctic waters range from oligotrophic regions to productive coastal embayments (Karl, 1991). The Bransfield and Gerlache Straits, located in the coastal zone of the Antarctic Peninsula, are characterized by a complex circulation pattern, involving waters from the surrounding Weddell Sea, Bellingshausen Sea and Drake Passage (Niiler et al., 1991). This coastal zone shows a wide spatial and temporal range of phytoplankton production (Priddle et al., 1986; Holm-Hansen and Mitchell, 1991; Karl et al., 1991a).

A mesoscale study in this area was carried out during the RACER program (November 1986-March 1987; Karl, 1991; Huntley et al., 1991) with the main objective of studying the physical and biological processes causing the high productivity observed in coastal waters of the Antarctic Peninsula (Huntley et al., 1991). Despite DOC was not measured, outputs from the RACER carbon model suggested production of a large amount of labile DOC (Karl et al., 1991a). Aristegui and Montero (1995) and Aristegui et al. (1996) suggested large exudation of DOC in the same area to explain their measurements of community respiration and the discrepancy between primary production measured by the ${ }^{14} \mathrm{C}$ and $\mathrm{O}_{2}$ methods.

Another three main conclusions from the RACER program will be specially considered in this work: 1) the upper mixed layer (UML) depth controlled the development of the spring bloom (Mitchell and Holm-Hansen, 1991); 2) a microbial food web dominated by phytoplankton was characteristic during the initial phase of the bloom (Karl et al, 1991b); and 3) the Bransfield Current could be important for transporting and redistributing biogenic material from eutrophic regions of the northern Gerlache Strait to the Drake Passage in a period of 15-30 days (Niiler et al., 1991). 
The main objective of the FRUELA project is the study of carbon fluxes in an area of elevated productivity in the Antarctic Ocean: the Gerlache and Bransfield Straits. The present work deals with the spatial and vertical variability of DOC. The origin and fate of the observed excess surface DOC is studied as well as the relationship of DOC with other water masses tracers.

\section{Material and Methods}

The results presented here correspond to a grid of four transects in the western basin of the Bransfield Strait and one transect along the Gerlache Strait, occupied from 10 to 18 December 1995 during the FRUELA'95 expedition, aboard the Antarctic R/V 'Hespérides'. The positions of the sampling stations are shown in Fig. 1.

Salinity and temperature were recorded by means of a conductivity-temperaturedepth (CTD) Mark IIIC probe. Water samples were collected with a General Oceanic rosette sampler (24 Niskin bottles of 10 l) attached to the CTD system.

Seawater samples for DOC analysis were collected on 27 stations spaced 5-10 miles at selected depths: surface, fluorescence maximum, $100 \mathrm{~m}$, bottom and three more depths depending on the bathymetry. Samples were collected with $100 \mathrm{ml}$ polyethylene syringes with teflon plunger tips and filtered by hand through Whatman Puradisc GF/F disposable filter devices $(0.7 \mu \mathrm{m}$ pore size) on polypropylene housing. The filtrate was drawn eventually into $50 \mathrm{ml}$ polyethylene containers. The filtering system and the containers used for DOC had been previously soaked on $0.1 \mathrm{~N} \mathrm{HCl}$, and rinsed with Milli-Q water. In addition, the containers were rinsed three times with $50 \mathrm{ml}$ of sample. Samples were immediately stored at $-70^{\circ} \mathrm{C}$ until analysis in the base laboratory, eight months later. This storage technique has demonstrated no artefactual results on the micromolar scale (Hansell and Carlson, 1998b). 
DOC determination was performed by high temperature catalytic oxidation (HTCO) with a commercial Shimadzu TOC-5000. The combustion quartz tube was filled with a $0.5 \%$ Pt on $\mathrm{Al}_{2} \mathrm{O}_{3}$ catalyst. Three to 5 replicate injections of $200 \mu$ l were performed per sample. The concentration of DOC was determined by subtracting the average peak area from the instrument blank area and dividing by the slope of the standard curve. The instrument blank is the system blank plus the filtration blank. The system blank was determined by subtracting the DOC in UV-Milli-Q to the total blank. Measurements made with the high sensitivity catalyst (Pt on silica wool) produced values $<2 \mu \mathrm{mol} \mathrm{C} \mathrm{l}^{-1}$ for fresh UV-Milli-Q water. The filtration blank (determined by filtering UV-Milli-Q water through the filtration system) was $<2 \mu \mathrm{mol} \mathrm{C}^{-1}$. Before sample analyses, the catalyst was washed by injecting UV-Milli-Q, for at least $12 \mathrm{~h}$, until the system blank was low and stable. The system blank was $<8 \mu$ mol $\mathrm{C}^{-1}$. The device was standardized with Potassium Hydrogen Phthalate (KHP). The coefficient of variation (C.V.) of the peak area for the 3-5 replicate analyses of each sample was $~ 1 \%$. The accuracy of our HTCO system has been tested within the international intercalibration exercise conducted by J. Sharp (Univ. of Delaware), with very satisfactory results (within $\pm 10 \%$; J. Sharp, pers. com.).

Seawater samples for particulate organic matter (POM), chlorophyll a (chl $a$ ), nutrients and oxygen were also collected. Sampling depths for POM were the same as DOC analysis; every $10 \mathrm{~m}$ between the surface and $100 \mathrm{~m}$ depth for chl $a$ and surface, every 20 m between $20 \mathrm{~m}$ and $100 \mathrm{~m}, 200,250$, every $100 \mathrm{~m}$ between $300 \mathrm{~m}$ and $600 \mathrm{~m}$, $800 \mathrm{~m}, 1000 \mathrm{~m}$ and every 300 or $500 \mathrm{~m}$ between $1000 \mathrm{~m}$ and bottom depending on bathymetry for nutrients.

A volume of $1 \mathrm{l}$ of sample was filtered through an oilless vacuum filtration system. Particulate organic carbon (POC) and nitrogen (PON) were collected on 
Whatman GF/F filters, which were dried on silica gel and frozen to $-70^{\circ} \mathrm{C}$ until analysis in the base laboratory. Measurements were carried out with a Perkin Elmer 2400 CHN analyzer. Combustion to $\mathrm{CO}_{2}$ and $\mathrm{NO}_{\mathrm{x}}$ was performed at $900^{\circ} \mathrm{C}$ and reduction of $\mathrm{NO}_{\mathrm{x}}$ to $\mathrm{N}_{2}$ at $640^{\circ} \mathrm{C}$. Chlorophyll $a$ was determined fluorometrically, with a Turner Designs 10000R fluorometer, after 90\% acetone extraction (Yentsch and Menzel, 1963). Samples for nutrients analyses were collected on $100 \mathrm{ml}$ polyethylene syringes and filtered by hand through Whatman Puradisc 25 disposable filters (polypropylene filter media: $0.45 \mu \mathrm{m}$ pore size) on polypropylene housing. The filtrate was drawn into $50 \mathrm{ml}$ polyethylene containers and analyzed immediately using standard segmented flow analysis procedures (Castro et al., this volume).

\section{Results and Discussion}

\subsection{Hydrographic conditions}

According to García et al. (this volume) silicate is a very good discriminator of water masses in the FRUELA area. To study the spatial variability of DOC, Chl $a$ and POC in relation to water masses, we have displayed the silicate distributions at two reference levels: the upper mixed layer (UML) and 200 m (Fig. 2b,c).

Figure 2a shows the UML depth $\left(\mathrm{Z}_{\mathrm{UML}}\right)$, calculated following Castro et al. (this volume). Shallower UMLs $(\leq 20 \mathrm{~m})$ were found in the southeastern corner of the Bransfield Strait and in the Gerlache Strait, with the exception of station 40. Stratification in the northeastern part of the Gerlache Strait was due to the presence of a warm $\left(\mathrm{T}>-1.0^{\circ} \mathrm{C}\right)$ and diluted $(\mathrm{S}<33.5)$ water layer. In the southeastern part of the Gerlache Strait and in the southeastern sector of the Bransfield Strait, melting ice favored the strong water column stratification (García et al., this volume). 
The horizontal distribution of silicate integrated over the UML (Fig. 2b) discerns between the Transition Zonal Water with Bellingshausen influence (TBW) and the Transitional Zonal Water dominated by Weddell Sea influence (TWW) in the Bransfield Strait (García et al., this volume). The silicate isoplet of $79 \mu \mathrm{mol} \mathrm{kg}{ }^{-1}$ coincides with the isohaline of 34.1 and can be considered the limit between TBW $\left(\mathrm{SiO}_{2} \leq 79 \mu \mathrm{mol} \mathrm{kg}{ }^{-1}\right)$ and TWW. The northeast advection of surface water from the Gerlache Strait is discerned by the highest silicate levels in the area $\left(\geq 84 \mu \mathrm{mol} \mathrm{kg}{ }^{-1}\right)$. At $200 \mathrm{~m}$ depth (Fig. 2c), the Bransfield Front separates the intrusion of Lower Circumpolar Deep Water (LCDW) with high silicate concentrations ( $>85 \mu \mathrm{mol} \mathrm{kg}{ }^{-1}$ ) from TWW with lower levels (García et al., this volume). In the Gerlache Strait, the high silicate levels $\left(>94 \mu \mathrm{mol} \mathrm{kg}{ }^{-1}\right.$ ) correspond to LCDW warmer and saltier ( $\mathrm{T}=$ $0.7 \pm 0.1{ }^{\circ} \mathrm{C}, \mathrm{S}=34.50 \pm 0.01$ ) than LCDW in the northwestern part of the Bransfield Strait $\left(\mathrm{T}=0.07 \pm 0.3{ }^{\circ} \mathrm{C} ; \mathrm{S}=34.41 \pm 0.06 ; \mathrm{SiO}_{2}=87 \pm 4 \mu \mathrm{mol} \cdot \mathrm{kg}^{-1}\right)$. In the BransfieldGerlache confluence lower silicate levels corresponds to the TWW. Below $400 \mathrm{~m}$, TWW fills the entire Bransfield Strait with a mean silicate concentration of $86 \pm 3 \mu$ mol $\mathrm{kg}^{-1}$ and salinity of $34.56 \pm 0.02$.

\subsection{Vertical DOC profiles}

The average DOC profile for the study area (mean \pm SD) decreased from $66 \pm 13 \mu$ mol C

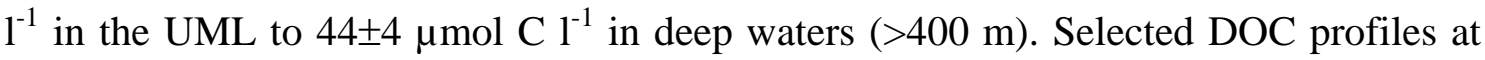
stn 40, in the Gerlache Strait; stn 74, in the Gerlache-Bransfield confluence; stn 103, in the Bransfield Strait; and stn 121, at the Bransfield Front (Fig. 3), cover all the observed vertical variability.

The correlation of DOC with density was low $\left(r^{2}<0.1\right)$ in the whole water column, indicating the low control of hidrography on the distribution of DOC. 
Stations 74 and 121 showed a DOC maximum at the base of UML (i.e. in the bottom layer of UML) as well as most of the sampling stations (70\%). Despite the similar Chl $a$ levels, DOC concentrations were very different between these stations. Concentration at the DOC maximum was higher in the Gerlache-Bransfield confluence

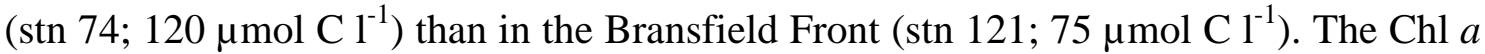
maximum at these stations $\left(>4 \mathrm{mg} \mathrm{m}^{-3}\right.$ ) was apparently shallower than the DOC maximum in agreement with the distributions of TOC found by Wedborg et al. (1998) at productive stations in the Weddell Sea.

Conversely, in other stations the DOC maximum can be located within the UML. This is the case of stn 40, where the DOC maximum was at $20 \mathrm{~m}$, coinciding with the subsurface Chl $a$ maximum $\left(\sim 4 \mathrm{mg} \mathrm{m}^{-3}\right)$. This station in the Gerlache Strait showed the highest DOC values in the study area, although the average DOC value in

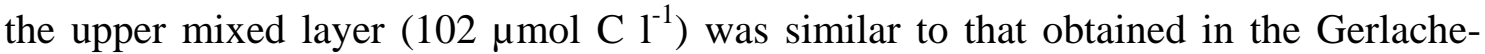

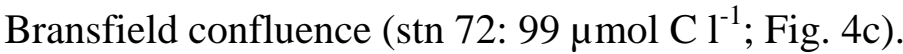

Despite the relatively high Chl $a$ levels at stn $103\left(>2 \mathrm{mg} \mathrm{m}^{-3}\right)$, DOC was low in

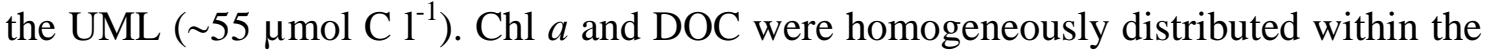
UML, as well as in most of the stations with low DOC and Chl $a$. This station showed the typical profile for the Bransfield Strait. The average DOC in the UML for this area

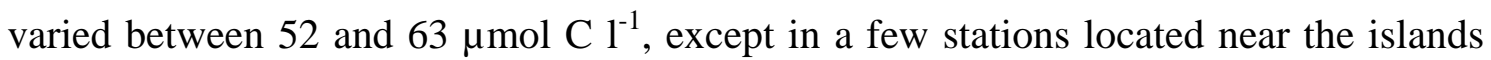
(Fig. 4c). On the contrary, most of the stations with high average values of DOC (ex.: stns $40,72,121)$, showed no uniform profiles within the UML, which points to net production processes being quicker than the time for homogenization.

Below the UML, DOC concentration decreases monotonically with depth,

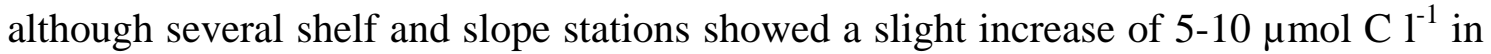
the bottom layer (stations: 39, 97, 99, 103 and 117). Several authors have obtained the 
same behavior for slope and abyssal stations (Williams et al., 1980; X. A. ÁlvarezSalgado and A. E. J. M Miller, unpubl.) which can be related to diffusion from the sediments of DOM younger than that in the overlying water (Bauer et al., 1995).

\subsection{Organic matter below the upper mixed layer}

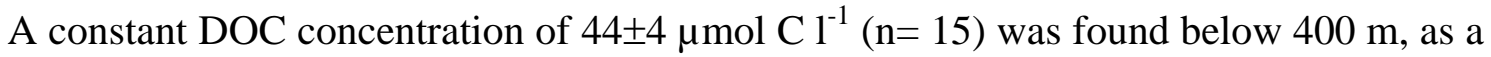
result of the homogeneous water mass there and the low bacterial activity at this depth range (Pedrós-Alió et al., this volume). This can be considered refractory DOC. It was similar to the DOC levels found by Kähler et al. (1997) in $6^{\circ} \mathrm{W}$, between $47^{\circ}$ to $60^{\circ} \mathrm{S}$ and Carlson et al. (1998) in the Ross Sea. This concentration is intermediate between the low levels recorded in the deep Pacific Ocean (34-40 $\mu$ mol C $\mathrm{l}^{-1}$ ) and the higher levels measured in the deep Atlantic Ocean ( 44-48 $\mu$ mol C l $^{-1}$; Hansell and Carlson, 1998b). Our baseline DOC is very close to the values reported by these authors for the Southern Ocean (about $42 \mu \mathrm{mol} \mathrm{C}{ }^{-1}$ ).

Following the distribution of silicate at $200 \mathrm{~m}$ depth (Fig 2c), DOC concentrations were studied to check the influence of the different water masses. The values of DOC at this depth showed an average concentration of $52 \pm 7 \mu \mathrm{mol}^{-1}$, i.e. only

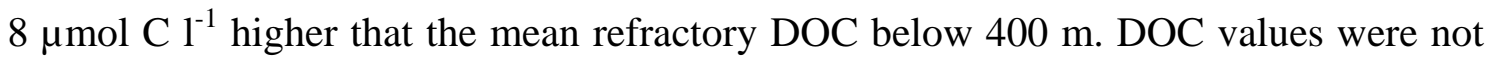
significantly different between LCDW and TWW $(\mathrm{t}(\mathrm{df}=14)=0.62, \mathrm{p}=0.55)$. The correlation between DOC and silicate was only $r^{2}=0.25(\mathrm{p}<0.001)$.

The fact that the DOC concentration at $200 \mathrm{~m}$ depth was mainly independent of water mass, indicate that the amount of DOC seems to be essentially refractory, although a minor fraction of semi-labile DOC (15\% of the total) was also present at this depth. 


\subsection{Organic matter in the upper mixed layer. The excess DOC}

The distributions of average Chl $a$ and POC (Fig. 4a, b) in the UML were quite similar. Maximum values of Chla and POC were found in the Gerlache Strait (4-6 mg Chl $a \mathrm{~m}^{-3}$

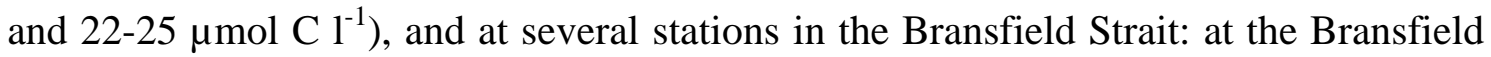

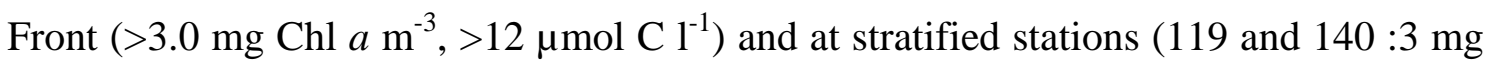
Chl $a \mathrm{~m}^{-3}, 16 \mu \mathrm{mol} \mathrm{C} \mathrm{l}{ }^{-1}$ ). Minimum values corresponded to stations located north of the

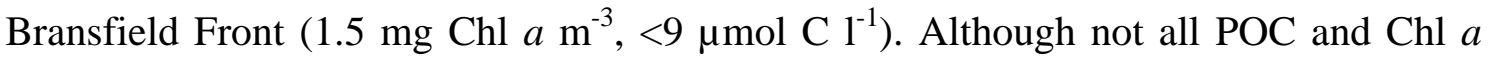
maxima coincided, the direct correlation (Model II; Sokal and Rolhf, 1995) between these variables for all samples (in the UML) of the study area was:

$$
\begin{gathered}
\text { POC }( \pm 3.9)=2.5( \pm 0.3)+4.3( \pm 0.3) \text { Chl } a \\
r^{2}=0.75, \quad \mathrm{n}=50, \quad \mathrm{p}<0.001
\end{gathered}
$$

The high correlation between POC and Chl $a$ (eq. 1) allow us to estimate the percentage of autotrophs by multiplying the slope of the regression by the average chlorophyll $a$ and dividing by the average POC. Autotrophs represent $\sim 80 \%$ of POC in the UML. The slope of equation 1, $4.3 \mathrm{~mol} \mathrm{C} \mathrm{g} \mathrm{Chl} a^{-1}$ (51.6 g C g Chl $a^{-1}$ ) was similar to the ratio used in the RACER program and it was considered typical for Antarctic phytoplankton (Mitchell and Holm-Hansen, 1991). The range of POC/Chl $a$ ratios found in this layer (32-192 g C g Chl $a^{-1}$ ) was within the values reported for Antarctic waters (between 11 and $416 \mathrm{~g} \mathrm{C} \mathrm{g} \mathrm{chl} a^{-1}$; Palmisano et al. 1985; El Sayed and Taguchi, 1981).

POC and PON were obviously coupled throughout the entire water column, and the direct correlation (Model II) was very high $\left(\mathrm{r}^{2}=0.95 ; \mathrm{p}<0.001\right)$. If we considered the UML, the direct correlation (Model II) between POC and PON for the study area was:

$$
\text { POC }( \pm 0.6)=0.35( \pm 0.17)+5.1( \pm 0.1) \text { PON }
$$




$$
r^{2}=0.97, \quad \mathrm{n}=54, \quad \mathrm{p}<0.001
$$

The slope of equation 2 is lower than the Redfield ratio and similar to that found in Antarctic waters (Copin-Montégut and Copin-Montégut, 1983; Pérez et al., 1994). This low $\mathrm{C} / \mathrm{N}$ ratio suggests that the environmental conditions were favorable for phytoplankton growth, as bacterial biomass (low $\mathrm{C} / \mathrm{N}$ ratios) made a little fraction of particulate organic matter (Pedrós-Alió et al., this volume). The direct $\mathrm{C} / \mathrm{N}$ ratio of POM was $5.3 \pm 0.5$ within the UML. These low POC/Chl $a$ and POC/PON ratios are typical of autotrophic systems (Holm-Hansen et al., 1989; Nelson et al., 1989).

The horizontal distribution of average DOC in the UML (Fig. 4c) showed

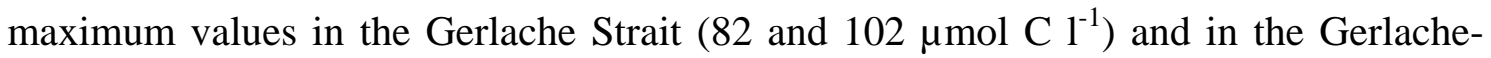

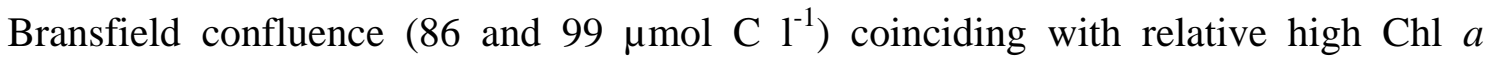
maximum values $\left(>3 \mathrm{mg} \mathrm{m}^{-3}\right)$. Minimum values of average DOC were measured within

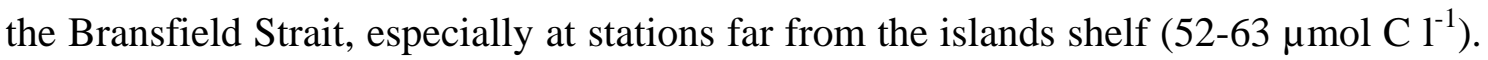
The direct correlation (Model II) between DOC and POC or Chl $a$ was only significant $\left(r^{2}=0.25\right)$ in the Gerlache Strait and Gerlache-Bransfield confluence. In these two areas a higher correlation was found between total organic carbon $(\mathrm{TOC}=\mathrm{DOC}+\mathrm{POC})$ and POC $\left(r^{2}=0.45\right)$.

An excess of DOC was observed in surface waters as compared to bottom waters

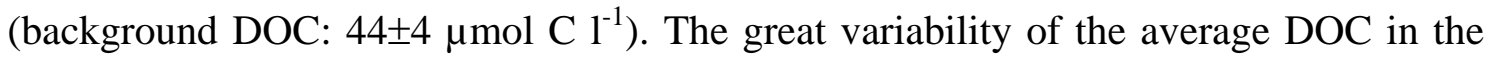
UML lead to a large range of excess DOC (8-58 $\mu$ mol $\left.\mathrm{C} \mathrm{l}^{-1}\right)$ with a mean value of $+22 \pm 13 \mu \mathrm{mol} \mathrm{C} \mathrm{l}^{-1}$ (average integrated DOC excess in the UML: $6.7 \pm 7.0 \mathrm{gC} \mathrm{m}^{-2}$ ) for the whole study area. So, 15 to $57 \%$ of the observed DOC in this layer was semilabile and labile DOC. The average excess DOC for the three contrasting regions: Gerlache 
Strait, Gerlache-Bransfield confluence and Bransfield Strait, varied between 17 and 36 $\mu$ mol C ${ }^{-1}$ (6 and $10 \mathrm{gC} \mathrm{m}^{-2}$; Table 1$)$.

The great variability of the excess DOC is larger than recently found in other

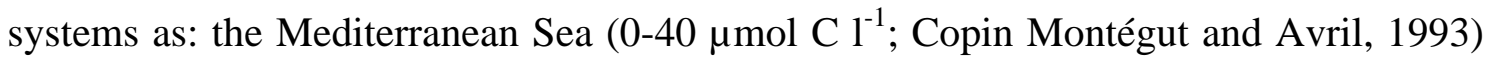

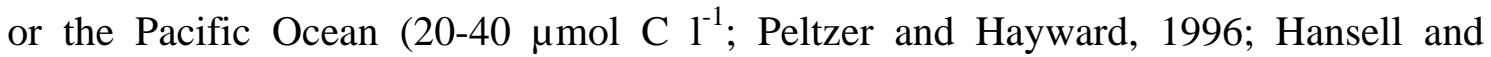
Waterhouse, 1997) and similar to that found in coastal upwelling areas as the NW Iberian coast (10-60 $\mu$ molC l ${ }^{-1}$; Doval et al., 1997) or the Arabian Sea (20-60 $\mu \mathrm{molC} \mathrm{l}^{-1}$; Hansell and Peltzer, 1998). We can group the DOC data in two different areas: A) Gerlache and Gerlache-Bransfield confluence (8 stations): relative high DOC concentrations and B) Bransfield Strait (18 stations): low DOC concentrations. The behavior of DOC was different in the recent study of Kähler et al. (1997) using the same HTCO method, in the eastern Weddell Sea. He did not find any variability of surface DOC concentration because DOC was not dependent of biological activity. The range of DOC in the Bransfield Strait was similar to that found by Carlson et al., (1998) in the Ross Sea where the low but labile surface DOC seems quickly recycling by bacterioplankton.

The average POC in the UML was 13.6 $\pm 5.1 \mu \mathrm{mol} \mathrm{C} \mathrm{l}^{-1}$. Therefore, the average excess DOC /(excess DOC + POC) was 0.59; i.e. 59\% of the 'potentially' degradable organic matter is in the dissolved form and $41 \%$ as suspended particles (Table 1 ). The average percentage was close to the $40-50 \%$ reported for the NW Iberian upwelling system (Doval et al., 1997), and far from a oligotrophic system as the Mediterranean Sea (89\% after seasonal accumulation; Copin-Montégut and Avril, 1993).

\subsection{Origin and fate of the DOC excess}


The main sources of the excess DOC in the study area could be: extracellular release by phytoplankton, sloppy-feeding by zooplankton and dissolution of fecal pellets, egestion by microzooplankton and cell lysis from viral infection (Carlson and Ducklow, 1995).

Melting ice did not seem to affect the DOC levels in the study area: although stns 94 and 115 at the Bransfield Strait and stns 34 and 43 at the Gerlache Strait showed lower salinity values $(<33.8)$, they did not show high DOC levels in contrast with the results found by Kahler et al., (1997) in other areas of the Southern Ocean.

In agreement with studies made during the RACER program, phytoplankton seems to be the dominant microplankton community during this cruise (Varela et al., this volume). Integrated zooplankton biomass between the surface and $200 \mathrm{~m}$ ranged from 0.19 to $0.99 \mathrm{gC} \mathrm{m}^{-2}$. Although there is no direct correlation between the integrated zooplankton biomass and integrated DOC in the UML in the study area, maximum integrated zooplankton biomass were located in the Gerlache Strait coinciding with maximum values of DOC (Anadón et al., this volume). Bacterial biomass was low compared to phytoplankton biomass ( $<25 \%$; Pedrós-Alió et al., this volume) probably due to the low temperature and virus lysis (Pedrós-Alió et al., this volume).

Average DOC production from phytoplankton at $5 \mathrm{~m}$ was between 0.4 to 4.1 mg C m${ }^{-3} \mathrm{~h}^{-1}$ for the whole study area (Morán and Estrada, this volume). The average values for the three selected regions (assuming they are similar throughout the UML) were: Gerlache Strait (2.33 mg C m $\left.{ }^{-3} \mathrm{~h}^{-1}\right)$, Gerlache-Bransfield confluence $(0.85 \mathrm{mg} \mathrm{C}$ $\mathrm{m}^{-3} \mathrm{~h}^{-1}$ ) and Bransfield Strait (1.33 $\left.\mathrm{mg} \mathrm{C} \mathrm{m} \mathrm{m}^{-3} \mathrm{~h}^{-1}\right)$. The average excess DOC could be produced from phytoplankton in about 6, 21 and 6 days, respectively, if losses were negligible. The estimated average geostrophic velocity in the Bransfield Current was $0.085 \mathrm{~m} \mathrm{~s}^{-1}$ during this cruise (Gomis et al., this volume), i.e. a flushing time of 15 
days within the sampling area. If the UML is maintained during the flushing time, the excess DOC of most of the stations sampled (regions A and C, 89\% of the total stations) could be net produced by phytoplankton. The higher DOC found at Gerlache Strait and Gerlache-Bransfield confluence seems to be the result of a rapid biological production. A slow production but large flushing time favored DOC accumulation in the oceanic oligotrophic gyres (Copin-Montégut and Avril, 1993). The large time necessary to produce DOC within the Gerlache-Bransfield confluence from phytoplankton (21 days), suggest that the advection from Gerlache is quite important.

Low bacterial biomass contributed to the observed DOC accumulation in the UML. This accumulated DOC can be coagulate and aggregate to POC as suggested Karl et al. (1991a) or can be exported horizontally and/or vertically. Turbulent diffusion is the major mechanism for the downward transport of DOC from surface to deep waters although stratification maintains the UML. The eddy diffusion flux of DOC from the UML to the waters below $400 \mathrm{~m}$ depth can be roughly estimated from $F=$ $K_{\mathrm{Z}} \cdot \triangle D O C / \triangle \mathrm{Z}$ (Copin-Montégut and Avril, 1993). $K_{\mathrm{Z}}$ is the turbulent diffusion coefficient, which can be calculated by the equation $K_{Z}=\varepsilon N^{2} \cdot R /(1-R)$. The dissipation rate $(\varepsilon)$ and the Richardson number $(R)$ have been set to constant values of $10^{-8} \mathrm{~m}^{2} \mathrm{~s}^{-3}$ and 0.2 respectively, for the open ocean (Copin-Montégut and Avril, 1993). Consequently, $K_{\mathrm{Z}}$ mainly depends on the square of the Brunt-Väisälä frequency, $N^{2}=$ $(\mathrm{g} / \rho) \cdot(\mathrm{d} \rho / \mathrm{d} Z)$. Values of $K_{Z}$ ranged from $5.5 \mathrm{~m}^{2} \mathrm{~d}^{-1}$ to $19.7 \mathrm{~m}^{2} \mathrm{~d}^{-1} . \Delta D O C / \Delta Z$ was simply calculated as $-\left(D O C_{\mathrm{UML}}-D O C_{\mathrm{UML}-400}\right) /\left[\left(400-\mathrm{Z}_{\mathrm{UML}}\right) / 2-\left(\mathrm{Z}_{\mathrm{UML}} / 2\right)\right]$ and varied from 0 to $11.8 \mathrm{mg} \mathrm{C} \mathrm{m}{ }^{-4}$. Finally, the resulting eddy diffusion fluxes ranged from $0 \mathrm{mg} \mathrm{C} \mathrm{m}^{-2} \mathrm{~d}^{-1}$ to $155 \mathrm{mg} \mathrm{C} \mathrm{m} \mathrm{m}^{-1}$ (average: $30.3 \mathrm{mg} \mathrm{C} \mathrm{m}^{-2} \mathrm{~d}^{-1}$ ). These numbers are extremely low when compared with the average excess DOC observed in the UML $\left(6.7 \mathrm{gC} \mathrm{m}^{-2}\right)$, confirming that stability although small, keep the DOC within the UML indicating that 
turbulent diffusion is not an important route to inject semilabile DOC in subsurface waters. Therefore, horizontal export seems to be the main fate of the excess DOC in the study area.

Acknowledgements. The authors wish to thank all the participants in the cruise FRUELA'95 and the crew of the 'BIO Hesperides' for their valuable help. We specially thank R. Anadón, M. Estrada, J. A. Morán, and C. Pedrós-Alió for providing zooplankton biomass, phytoplankton exudation and bacterial biomass data. A fellowship from the EC MAST2 project CT93-0065 allowed M.D.D. to carry out this work. X.A.A.-S. was funded by a 'Contrato de Incorporación' of the Spanish 'Ministerio de Educación y Ciencia'. C.G.C. was funded by a contract from the EC MAS3-CT96-0060 project. This work was financed by CICYT contract no. ANT941168-E. 


\section{References}

Anadón, R., Fernández, E., Varela, M., Gasol, J.M., Vaqué, D., Zapata, M., (this volume) Size dependent particle flux in the Antarctic Peninsula area. Deep-Sea Research II,

Aristegui, J., Montero, M.F., 1995. Plankton community respiration in Bransfield Strait (Antarctic Ocean) during austral spring. Journal Plankton Research 17, 1647-1659

Aristegui, J., Montero, M.F., Ballesteros, S., Basterretxea, G., Van Lenning, K. 1996. Planktonic primary production and microbial respiration measured by $14 \mathrm{C}$ assimilation and dissolved oxygen changes in coastal waters of the Antarctic Peninsula during austral summer: implications for carbon flux studies. Marine Ecology Progress Series 132, 191-201

Bauer, J.E., Reimers, C.E., Druffel, E.R.M., Williams, P.M. 1995. Isotopic constraints on carbon exchange between deep ocean sediments and seawater. Nature, 373, 686689

Carlson, C.A., Ducklow, H.W, Michaels, A.F. 1994. Annual flux of dissolved organic carbon. Nature, 371, 405-408

Carlson, C.A., Ducklow, H.W. 1995. Dissolved organic carbon in the upper ocean of the central equatorial Pacific Ocean, 1992: daily and finescale vertical variations. Deep-Sea Research II, 42, 639-656.

Carlson, C.A., Ducklow, H.W., Hansell, D.A., Smith, W.O. 1998. Differences in ecosystem dynamics between spring blooms in the Ross Sea polynya and the Sargasso Sea reflected by contrasts in dissolved and particulate organic carbon partitioning. Limnology and Oceanography 43, 375-386

Castro, C.G, Rios, A.F., Doval, M.D., Perez, F.F. (this volume) Spatiotemporal variability of nutrient utilization and chlorophyll distribution in the upper mixed 
layer during FRUELA95 and FRUELA96 cruises (Antarctica). Deep-Sea Research II,

Copin-Montégut, G., Avril, B. 1993. Vertical distribution and temporal variation of dissolved organic carbon in the North Western Mediterranean Sea. Deep-Sea Research I, 40, 1963-1972

Copin-Montégut, C., Copin-Montégut, G. 1983. Stoichiometry of carbon, nitrogen, and phosphorus in marine particulate matter. Deep-Sea Research I, 30, 31-46

Dafner, E.V., 1992. Dissolved organic carbon in waters of the Polar Frontal Zone of the Atlantic Antarctic in the spring-summer season of 1988-1989. Marine Chemistry, $37,275-283$

Dafner, E.V., Selin, P.Y. 1995 Organic matter in waters of the SW Atlantic Sector of the Southern Ocean. Geo Journal, 35.1, 71-77

Dawson, R., Schramm, W., Bölter, M. 1985. Factors influencing the production, decomposition and distribution of organic and inorganic matter in Admiralty Bay, King George Island. In: W. R. Siegfried, P. R. Condy and R. M. Laws (eds) Antarctic nutrient cycles and food webs. Springer, Berlin, pp. 109-114

Doval, M.D., Álvarez-Salgado, X.A., Pérez, F.F. 1997. Dissolved organic matter in a temperate embayment affected by coastal upwelling. Marine Ecology Progress Series, 157, 21-37

Doval, M.D., Hansell D.A. 2000. Organic carbon and apparent oxygen utilization in the western South Pacific and the central Indian Oceans. Marine Chemistry 68: 249264.

El-Sayed, S.Z., Taguchi, S. 1981. Primary production and standing crop of phytoplankton along the ice-edge in the Weddell Sea. Deep-Sea Research, 28A, 1017-1032 
García, M.A., Castro C.G., Ríos A.F., Doval M.D., Rosón G., Gomis D., López, O., (this volume). Water masses and distribution of physico-chemical properties in the western Bransfield Strait and Gerlache Strait during Austral summer1995/96. Deep Sea Research II.

Gomis, D., García, M.A, López, O., Pascual, A. (this volume) Quasi-geostrophic 3D circulation and mass transport in the western Bransfield Strait during austral summer 1995/96. Deep-Sea Research II

Hansell, D.A., Waterhouse, T.Y. 1997. Control of the distributions of organic carbon and nitrogen in the eastern Pacific Ocean. Deep-Sea Research I, 44, 843-857

Hansell, D.A., Peltzer, E.T. 1998. Spatial and temporal variations of total organic carbon in the Arabia Sea. Deep-Sea Research II, 45, 2171-2193.

Hansell, D.A., Carlson, C.A., 1998a. Net community production of dissolved organic carbon. Global Biogeochemical Cycles, 12, 443-453

Hansell, D.A., Carlson, C.A. 1998b. Deep ocean gradients in concentration of dissolved organic carbon. Nature , 395, 263-266

Holm-Hansen, O., Mitchell, B.G., Hewes, C.D., Karl, D.M 1989. Phytoplankton blooms in the vicinity of Palmer Station, Antarctica. Polar Biology, 10, 49-57

Holm-Hansen, O., Mitchell, B.G 1991. Spatial and temporal distribution of phytoplankton and primary production in the western Bransfield Strait region. Deep-Sea Research II, 38, 961-981

Huntley, M., Karl, D.M., Niller, P., Holm-Hansen, O. 1991. Research on Antarctic Coastal Ecosystem Rates (RACER): an interdisciplinary field experiment. Deep-Sea Research II, 38, 911-943 
Kähler, P., Björnsen, P.K., Lochte, K., Antia, A. 1997. Dissolved organic matter and its utilization by bacteria during spring in the Southern Ocean. Deep-Sea Research II, 44, 341-353

Karl, D.M., 1991. RACER: Research on Antarctic coastal ecosystem rates. Preface. DeepSea Research II, 38, v-vii

Karl, D.M., Tilbrook, D.B., Tien, G. 1991a. Seasonal coupling of organic matter production and particle flux in the western Bransfield Strait, Antarctica. Deep-Sea Research II, 38, 1097-1127

Karl, D.M., Holm-Hansen, O., Taylor, G.T., Tien, G., Bird, D.F. 1991b. Microbial biomass and productivity in the western Bransfield Strait, Antarctica during the 1986-87 austral summer. Deep-Sea Research II, 38, 1029-1057

Karl, D.M., Christian, J.R., Dore, J.E., Letelier, R.M. 1996. Microbiological oceanography in the region west of the Antarctic Peninsula: Microbial dynamics, nitrogen cycle and carbon flux. Foundations for Ecological Research West of the Antarctic Peninsula. Antarctic Research Series, 70, 303-332.

Legendre ,L., Fèvre, J.Le 1995. Microbial food webs and the export of biogenic carbon in the oceans. Aquatic Microbial Ecology, 9, 69-77

Mitchell, B.G., Holm-Hansen, O. 1991. Observations and modelling of the Antarctic phytoplankton crop in relation to mixing depth. Deep-Sea Research II, 38, 981-1009 Morán, X.A.G., Estrada, M. (this volume) Phytoplanktonic DOC and POC production in the Bransfield and Gerlache Straits as derived from kinetic experiments of ${ }^{14} \mathrm{C}$ incorporation. Deep-Sea Research II

Nelson, D.M., Smith, W.O., Muench, R.D., Gordon, L.I., Sullivan, C.W., Husby, D.M. 1989. Particulate matter and nutrient distribution in the ice-edge zone of the 
Weddell Sea: relationship to hydrography during later summer. Deep-Se Research, 36, 191-209

Niiler, P.P., Amos, A., Hu, J.H. 1991. Water masses and 200m relative geostrophic circulation in the western Bransfield Strait region. Deep-Sea Research II, 38, 943961

Palmisano, A.C., Soohoo, J.B., Sullivan, C.W. 1985. Photosynthesis-irradiance relationships in sea ice microalgae from McMurdo Sound, Antarctica. Journal of Phycology, 21, 341-346

Pedrós-Alió, C., Vaqué, D., Guixa-Boixereu, N., Gasol, J.M. (this volume) Bacterioplankton biomass and heterotrophic production in western Bransfield Strait, southern Drake Passage and Gerlache Strait, Antarctica during the 1995-96 austral summer. Deep-Sea Research II

Peltzer, E.T., Hayward, N.A 1996. Spatial and temporal variability of total organic carbon along $140^{\circ} \mathrm{W}$ in the equatorial Pacific Ocean in 1992. Deep-Sea Research II, 43, $1155-1180$

Pérez, F.F., Figueiras, F.G., Ríos, A.F. 1994. Nutrient depletion and particulate matter near the ice-edge in the Weddell Sea. Marine Ecology Progress Series, 112, 143-153

Priddle, J., Hawes, I., Cellis-Evans, J., Smith, T.J. 1986. Antarctic aquatic ecosystems as habitants for phytoplankton. Biological Reviews, 61, 199-238

Sokal, R.R, Rolhf, F.J. 1995. Biometry. Freeman and Company (eds), New York, 887 pp

Skoog, A., Wedborg, M. 1994. Organic carbon and humic substances in the Weddell Sea. Reports on Polar Research, 135, 168-169 
Thingstad, T.F., Hagström, A., Rassoulzadegan, F. 1997. Accumulation of degradable DOC in surface waters: Is it caused by a malfunctioning microbial loop? Limnology Oceanography, 42, 398-404

Varela, M., Fernández, E., Serret, P., Marañón, E. (this volume). Size-fractionated phytoplankton biomass and primary production in the western Bransfield and Gerlache Straits (Antarctica) during summer. Deep-Sea Research II,

Wedborg, M., Hoppema, M., Skoog, A. 1998. On the relation between organic and inorganic carbon in the Weddell Sea. Journal of Marine Systems 17, 59-76

Wiebinga, C.J., De Baar, H.J.W. 1998. Determination of the distribution of dissolved organic carbon in the Indian sector of the Southern Ocean. Marine Chemistry, 60, $185-201$

Williams, P.M., Carlucci, A.F., Olson, R. 1980. A deep profile of some biologically important properties in the central North Pacific gyre. Oceanologica Acta, 3, 471476

Yentsch, C.S., Menzel, D.W. 1963. A method for the determination of phytoplankton chlorophyll and phaephytin by fluorescence. Deep-Sea Research, 10, 221-231 
Table 1.

Average and standard deviation of the depth-integrated excess DOC (DOCex= DOC $_{\text {UML }}-44 ; \mu$ mol C l $\left.{ }^{-1}\right)$, POC $\left(\mu m o l ~ \mathrm{C} \mathrm{l}^{-1}\right)$ and excessDOC /(excessDOC + POC) ratio in the UML; DOC production from phytoplankton (DOCpr; $\mathrm{mg} \mathrm{C} \mathrm{m} \mathrm{m}^{-3}$ ) and percentage of extracellular release (PER) at $5 \mathrm{~m}$ (taken from Moran and Estrada, this volume) for the three areas considered: Gerlache Strait (Gerlache S.); GerlacheBransfield confluence (Gerl.-Bransf. conf.) and Bransfield Strait (Bransfield S.).

\begin{tabular}{cccccc}
\hline Region & $\begin{array}{c}\text { DOCex } \\
\left.(\mu \mathrm{mol} \mathrm{C} \mathrm{l})^{-1}\right)\end{array}$ & $\begin{array}{c}\text { POC } \\
\left(\mu \mathrm{mol} \mathrm{C} \mathrm{l}^{-1}\right)\end{array}$ & $\begin{array}{c}\text { DOCex/ } \\
(\mathrm{DOCex}+\mathrm{POC})\end{array}$ & $\begin{array}{c}\text { DOCpr } \\
\left(\mathrm{mg} \mathrm{C} \mathrm{m}^{-3} \mathrm{~h}^{-1}\right)\end{array}$ & $\begin{array}{c}\text { PER } \\
\%\end{array}$ \\
\hline Gerlache S. & $27 \pm 18$ & $17.8 \pm 4.7$ & $0.55 \pm 0.16$ & 2.33 & 13 \\
Gerl.-Bransf. conf. & $36 \pm 13$ & $17.4 \pm 5.0$ & $0.64 \pm 0.11$ & 0.85 & 17 \\
Bransfield S. & $17 \pm 6$ & $11.9 \pm 4.1$ & $0.57 \pm 0.10$ & 1.33 & 26 \\
\hline
\end{tabular}

Note: The stations sampled for DOC within the three regions were:

Gerlache Strait: 34, 37, 39, 40, 43,

Gerlache-Bransfield confluence: 47, 72,74

Bransfield Strait: 52, 76, 79, 81, 94, 97, 99, 101, 103, 115, 117, 119, 121, 123, 138, 140 , 142, 144 


\section{Figure Captions}

Figure 1. Map of the DOC sampling grid consisting of four transects in the western basin of the Bransfield Strait and one transect along the Gerlache Strait, during the FRUELA'95 cruise. Open circles marked selected stations presented in Figure 3

Figure 2. Spatial distribution of a) upper mixed layer depth ( $\left.Z_{U M L}, m\right)$, b) averaged depth-integrated silicate $\left(\mu \mathrm{mol} \mathrm{\textrm {kg } ^ { - 1 }}\right.$ ) in the upper mixed layer and c) silicate at 200 m depth ( $\mu$ mol kg ${ }^{-1}$ ). TBW: Transition Zonal Water with Bellingshausen Sea influence; TWW: Transition Zonal Water with Weddell Sea influence; LCDW: Lower Circumpolar Deep Water; B.F.: Bransfield Front

Figure 3. DOC $\left(\mu \mathrm{mol} \mathrm{l}^{-1}\right)$, sigma theta $\left(\gamma ; \mathrm{Kg} \mathrm{m}^{-3}\right)$ and chl $a\left(\mathrm{mg} \mathrm{m}^{-3}\right)$ vertical profiles at selected stations in the studied area: a) stn 40, b) stn 74, c) stn 103 and d) stn 121

Figure 4. Spatial distribution of depth-integrated in the upper mixed layer a) chlorophyll $a\left(\mathrm{mg} \mathrm{m}^{-3}\right)$, b) POC $\left(\mu \mathrm{mol} \mathrm{l}^{-1}\right)$ and c) DOC $\left(\mu \mathrm{mol} \mathrm{l} \mathrm{l}^{-1}\right)$ 


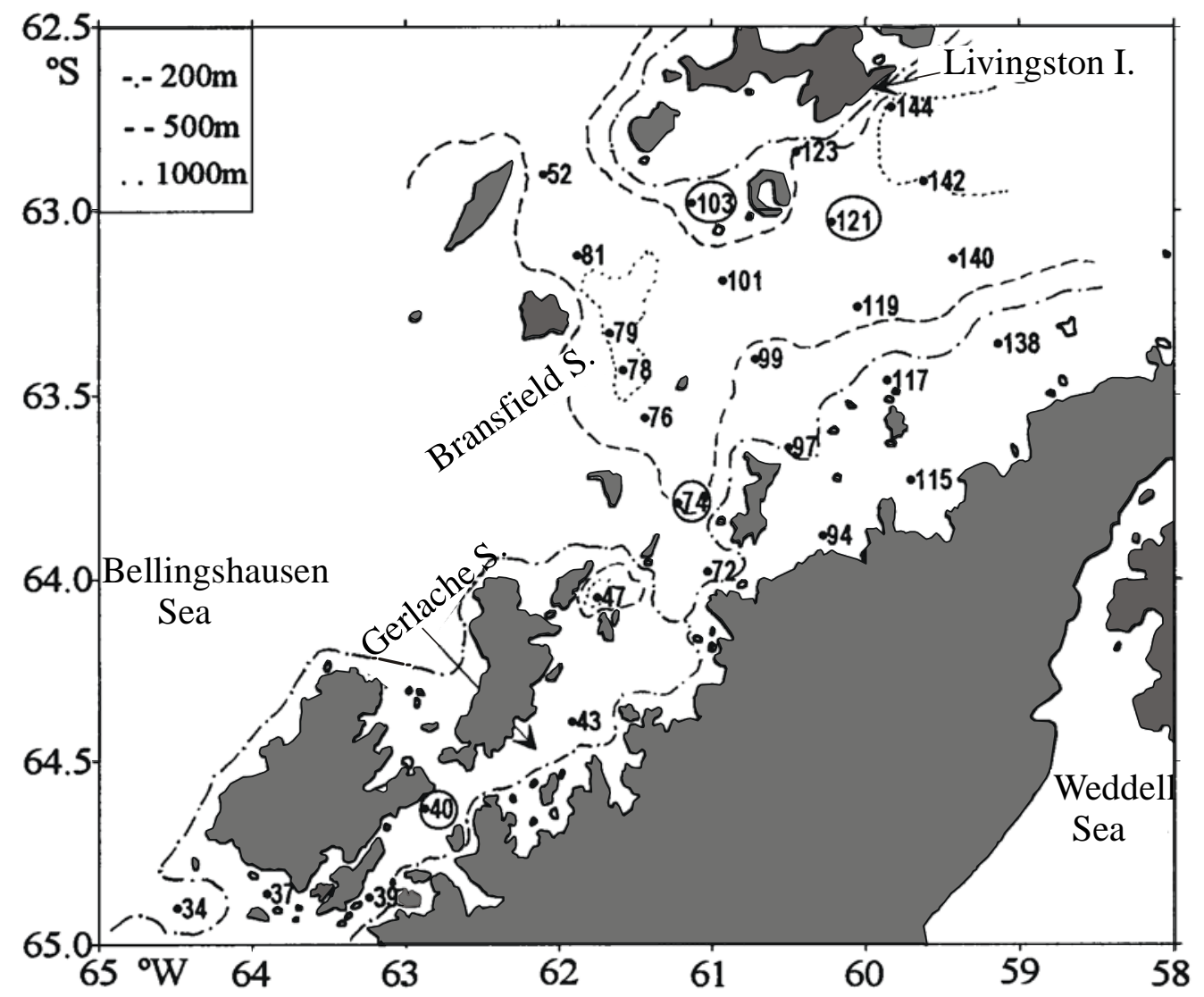

(Figura 1) 


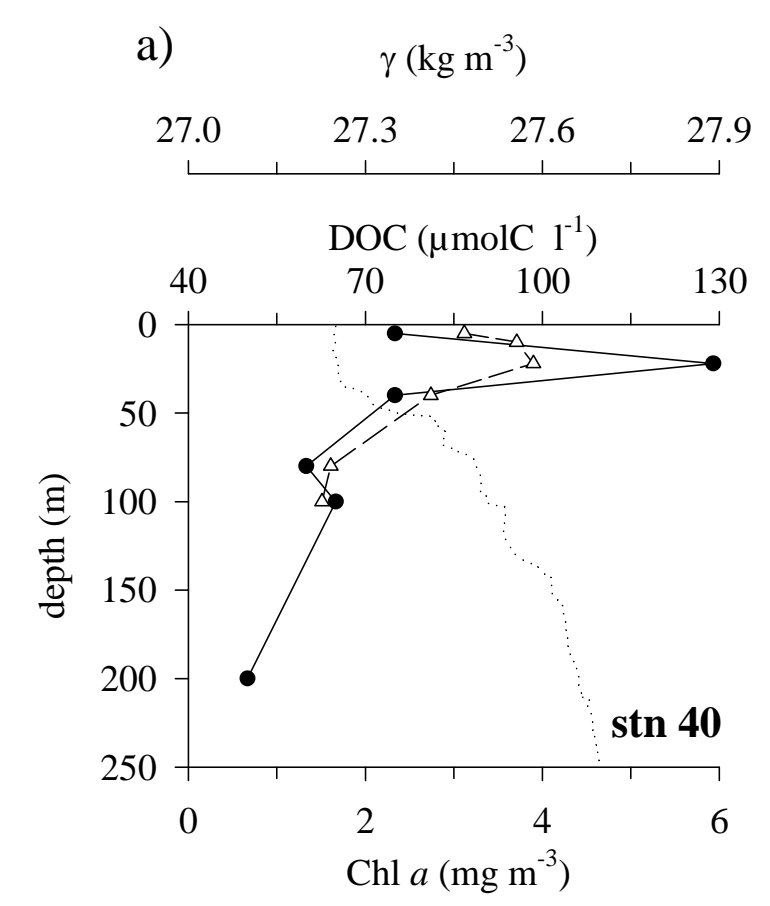

b)
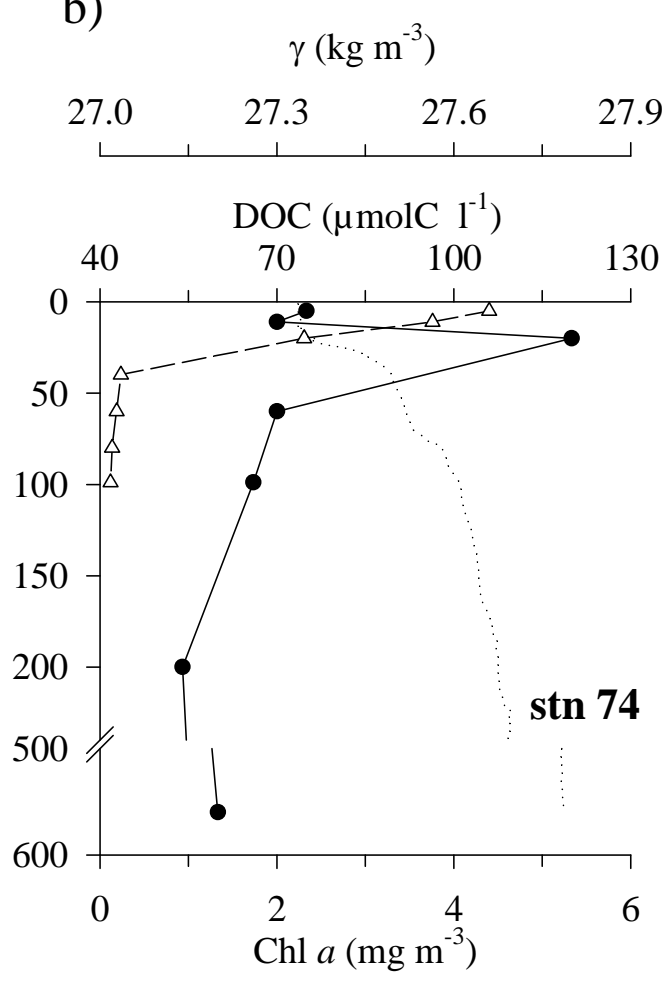

C)

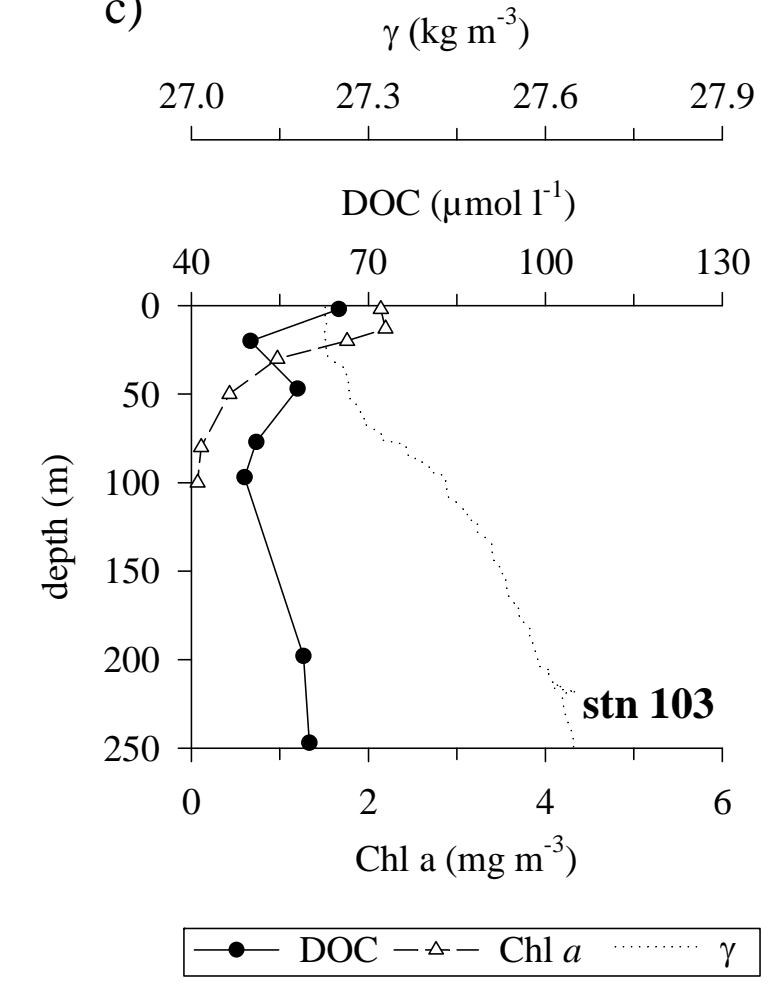

d)
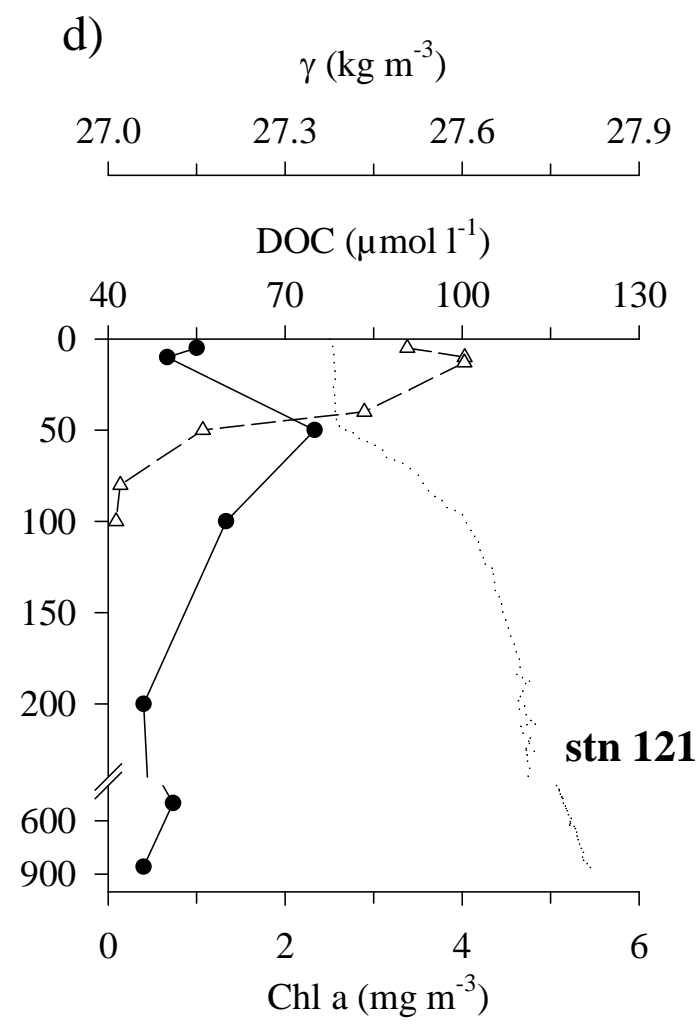

(Figure 3) 
a

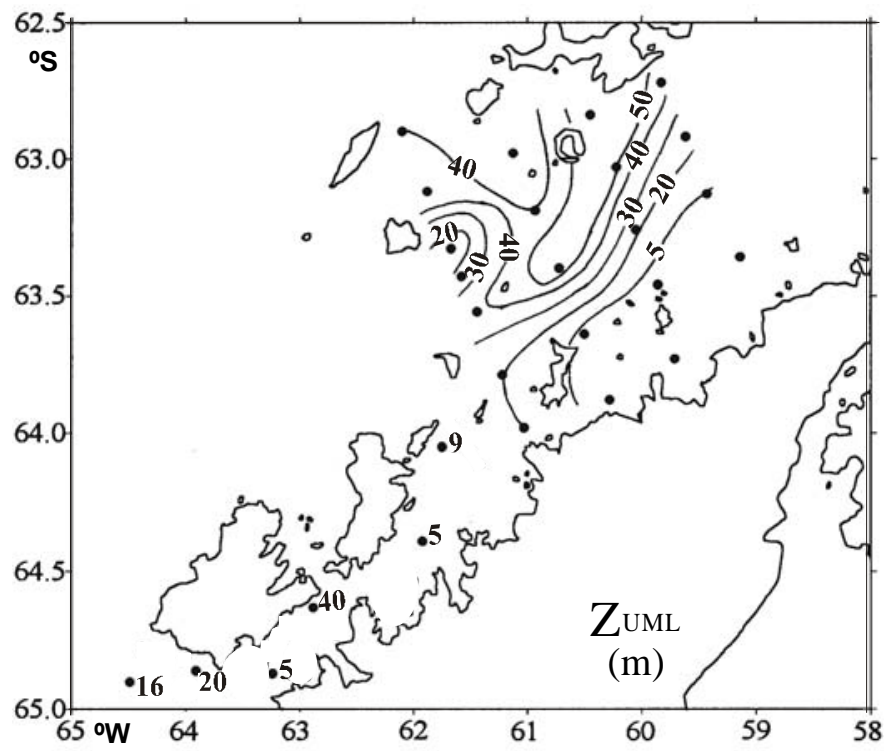

b

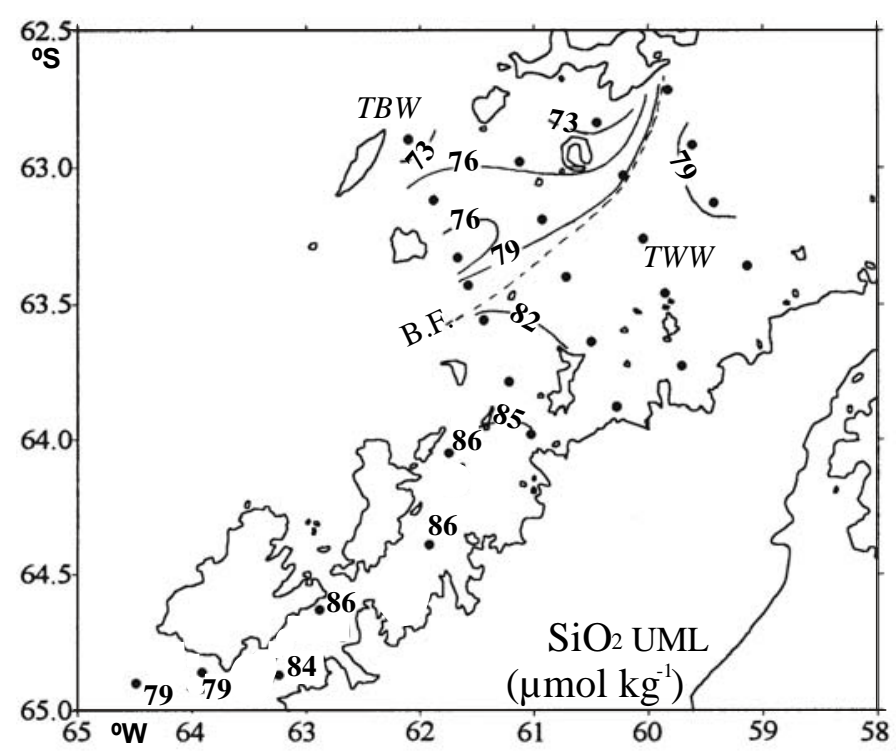

C

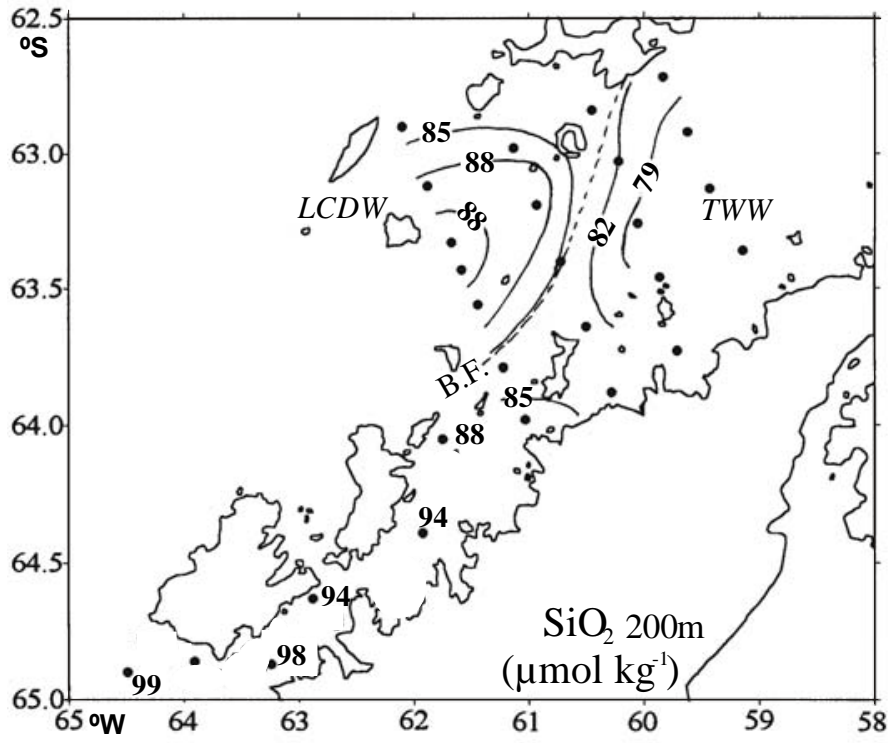

(Figure 2) 
a

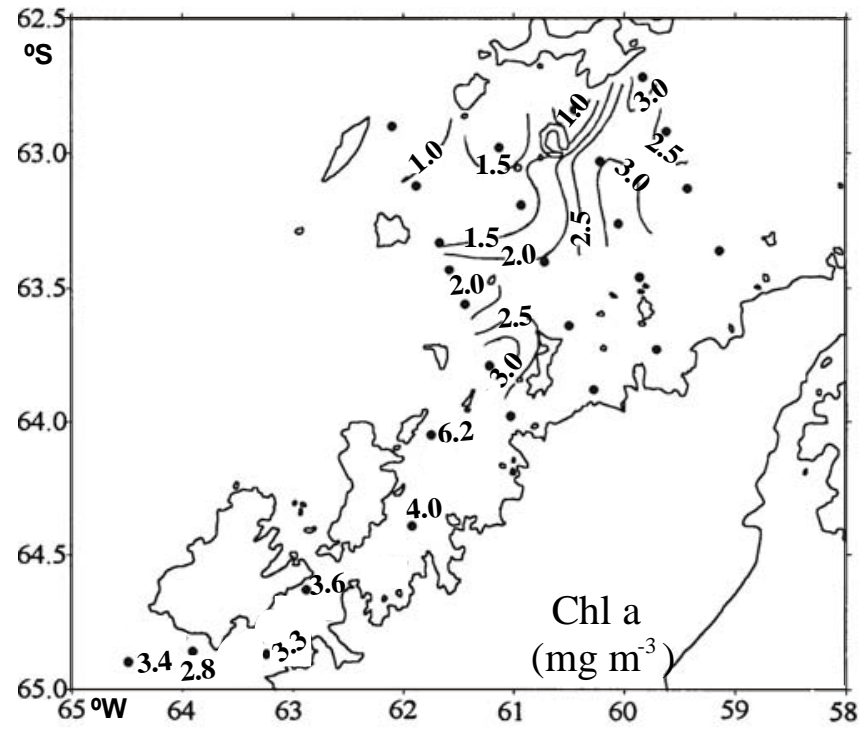

b

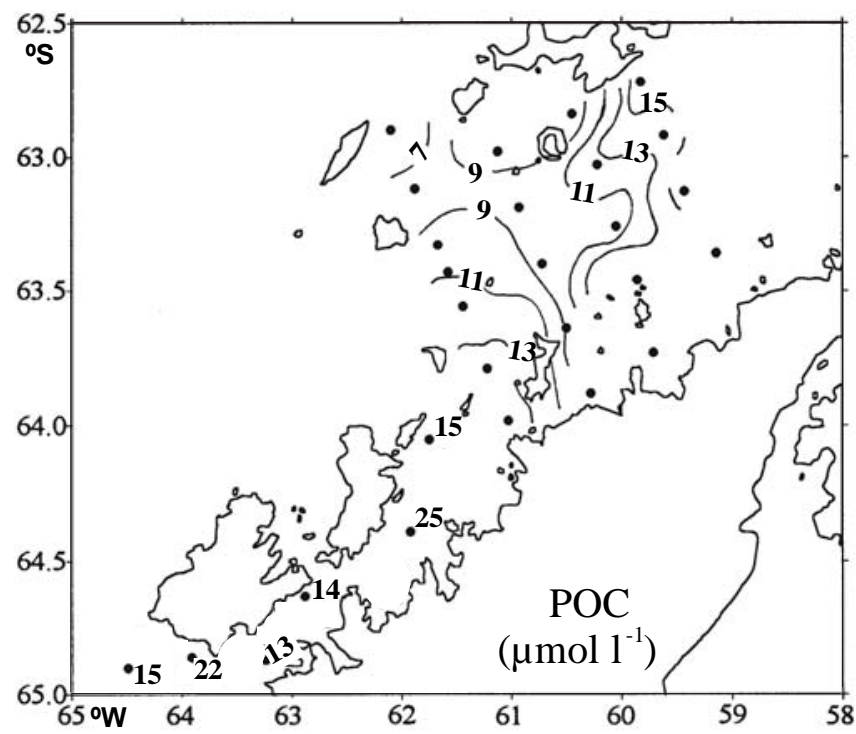

C

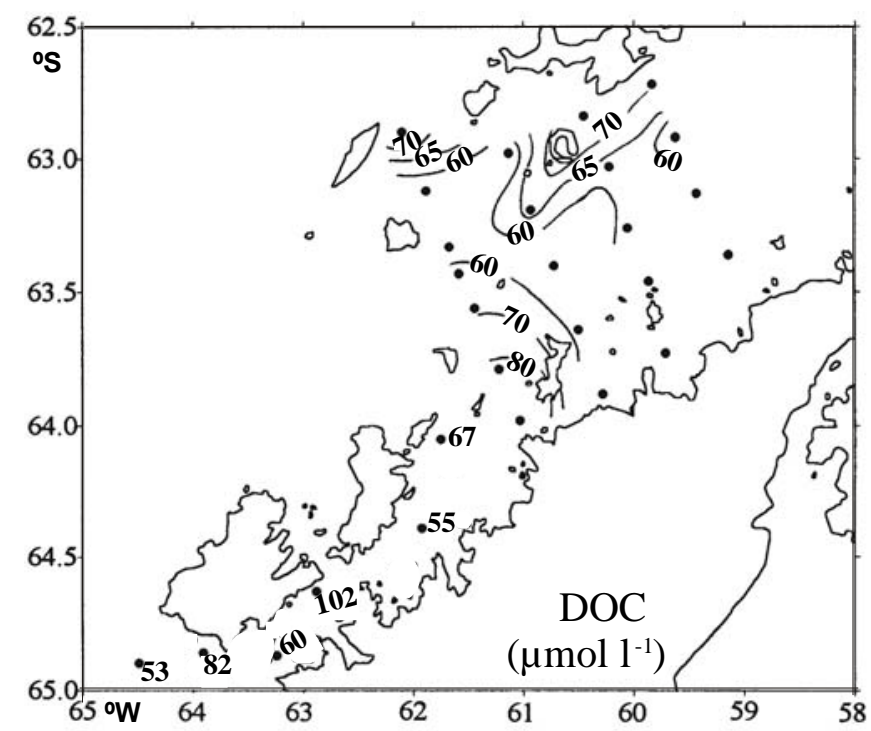

(Figure 4) 